\title{
The Hobo-Sexual: A Connective History
}

\section{HEATHER TAPLEY}

Heather Tapley is a doctoral candidate in the Department of English at the University of Alberta where she is writing her dissertation, HoboSexual Pedestrian Rhetorics: Recontextualizing the American City as Hobohemia. Part of that dissertation, this piece develops the hobo-sexual as a figure of queer sex and work practices able to extend the scope of both American lesbian and hobo history. Responses may be sent to her viaemail (htapley@ualberta.ca).

I $\mathrm{t}$ was a find: popular feminist Susan Faludi's new book, Stiffed: The Betrayal of the American Man, in hard cover at a paperback price. But as I leaned on the counter of my local feminist bookstore, scene of numerous sales of Faludi's Backlash: The Undeclared War Against American Women, watching my fellow dyke cashier stuff my purchase and its yellow receipt into a bag, I heard the words against which I would write this article: "Sell out. Faludi's a sell out," said she from behind me in line, a local self-proclaimed lesbian feminist sporting a professionally dyed high and tight hair cut and a leather jacket that must have made Danier smile.

I open with this anecdote not because my own research relies on Faludi's text, nor because I necessarily want to champion her shift to masculinity studies, but because the scene speaks to the dangerous rigidity of a lesbian-feminist identity politics capable of devaluing scholarship that strays from a deliberate focus on women. Such perspectives may very well lead to what Rosemary Hennessy describes in Profit and Pleasure as "dead identities [that] are not open to history" (228). Without promoting a complete erasure of identity politics, Hennessy calls for a reworking of identities that opens "the identity form 'I am' to history" (230). Rather than dismiss scholarship like Faludi's - scholarship that focuses on working-class 


\section{2 / Tapley}

men, for instance - Hennessy's theory of a coalition politics works to connect various identities, including the working poor male and lesbian. Hennessy traces their connections by drawing attention to the discourses of "sensation and affect" that have historically organized desire into categories of "allowed and outlawed human needs" (217). In response to such limitations, Hennessy promotes the "disidentifying subject" who practices the "process of unlearning that opens up the identities we take for granted to the historical conditions that make them possible" (229). She shows us how to imagine the possibility of forging strategic alliances by connecting differences among those groups traditionally divided and conquered under capitalist regimes. In short, she envisions a "powerful and monstrous collective opposition of all of capitalism's disenfranchised subjects" (229).

What follows is an attempt at just the kind of connective history Hennessy proposes. Adopting Hennessy's posture of disidentification enables me as an academic to begin making sense of the occasional, yet recurring, image of the hobo in lesbian literature. In "This Huge Light of Yours" Joan Nestle recounts her participation in a civil rights march on Selma, Alabama, during which she and others huddled "like hobos" (63) around garbage cans filled with fire. In Chelsea Girls Eileen Myles recounts her memories of "big prints of comical hoboes" (193) that littered the walls of her parents' summer rental. And Sarah Schulman makes overt references to Jack Kerouac in Girls, Visions and Everything. These associative images prompted me to research American hobo subcultures in the hope of locating a segment of lesbian literary history in the rich tradition of male anticapitalist rhetoric already established in American literature, from Jack London to the Beats. What caught my interest, instead, was a historical intersection of not-for-profit sex and work practices capable of exposing many of the outlawed needs of the unskilled labor force on which U.S. capitalism is built. Rather than formulate a distinct lesbian literary history, then, I 'sell out' - or suspend - my separatism (both political and scholarly) in order to produce another, connective figure through which lesbians can speak and recover a piece of their own history. I call this figure the hobo-sexual.

I understand the hobo-sexual as an intersection of a work ethic and a sexuality that overlap in the realm of what Georges Bataille calls "non-productive expenditure" ("Notion" 116). According to 
Bataille, the right to consume, conserve, and acquire is deemed appropriate behavior, while the right to lose, or to expend without profitable goal, is rarely considered a suitable practice in any place deemed civilized. ${ }^{1}$ The hobo-sexual, then, is a combination of notfor-profit work and sex practices that privileges outlawed needs over production and possession, a figure who has "a complete contempt for riches" and who often "refuses to work," making "life on the one hand an infinitely ruined splendor, and on the other, a silent insult to the laborious lie of the rich" (Accursed Share 76-77).

For my own purposes as a scholar of American literature, I have located this figure in American literary history, but in no way do I want to suggest that the hobo-sexual is solely a production of the United States, nor do I propose that the historical research that follows be considered a complete history of such a figure. In mapping the hobo-sexual, I draw predominantly on the work of Nels Anderson, born in 1889 , whose own hoboing practices greatly influenced his sociological research on hobos while enrolled at the University of Chicago. Based on direct participation and observation, Anderson's The Hobo: The Sociology of the Homeless Man, published in 1923 to inaugurate the University of Chicago Press's Sociological Series, not only offers a wealth of information regarding hobo subculture without the prevailing moral high ground regarding sexual practices, but also concentrates on the more unfamiliar hobo who traversed the U.S.A. before the Great Depression of the 1930s.

\section{Historicizing the American Hobo}

Since its first use in the English language in 1889, "hobo" has always signified a rather uncivilized place in regard to the United States

'The problems with Bataille's "The Notion of Expenditure" for this project, however, are duly noted. In his use of "potlatch" as a practice of "non-productive expenditure," Bataille emphasizes "the spectacular destruction of wealth" of a Tlingit chief who slashes "the throats of his own slaves." This "gift" is 'repaid' by his rival in the form of "the slaughter of a greater number of slaves." Bataille, then, does not emphasize slavery as a form of colonization but, instead, redirects his audience to read "the power to lose ... acquired by a rich man" as his "desire to destroy" (121-23). My use of Bataille's nonproductive expenditure, however, is located in the history of the hobo-sexual who maintains such a practice from within a site of loss. In Volume 1 of The Accursed Share, Bataille discusses the notion that when potlatch is given by the rich it is not necessarily a pure gift of nonreciprocity, as the giver receives "rank." Instead, "the true luxury and the real potlatch" belong to "the poverty stricken, that is, to the individual who lies down and scoffs" (76). 
agenda. ${ }^{2}$ Although historically catalogued as primarily white and male, his inability and/or ${ }^{3}$ refusal to adhere to the map of capitalism designed to engender career, home, and family, its emphasis on stasis and acquisition - renders the hobo a deviant of the nation he traverses. ${ }^{4}$ Considered an asocial figure with no fixed abode, the hobo moves for the most part alone and lives deliberately by wandering and working sporadically in various cities as an unskilled laborer of predominantly ditch digging, coal shoveling, and railway construction. According to Anderson, the typical practice of the hobo is to earn simply enough wages at each urban stop for the sustenance required to maintain his wanderlust - or his pathological need to move (82-85). ${ }^{5}$ In essence, the hobo works predominantly to eat and sleep in order to maintain his health and, in turn, his mobility; he resists the practice of the model consumer who rests and invests, as well as accumulates, in the commodified city. Rather, he usually eats and sleeps with fellow transients in the "hobo jungles," areas located on the outskirts of town, relatively free from the surveillance of the law. Here hobos share food, stories, politics, and newspapers from various states (16-20).

Of course, he does spend money. According to Anderson, "when hobos are in town with money to spend they 'go the limit' while it lasts, and then they go out to work" again (140). This practice of going the limit, however, rejects the standard custom of accumulation.

${ }^{2}$ According to the Oxford English Dictionary, "hobo" demarcated the difference between the "tramp," who did not work, and the itinerant unskilled worker who did. But as Allsop reminds us, while the westward expansion of the nineteenth century required unskilled laborers, the employment advertisements note a particular preference: men of "constant employment," meaning "two years," and "with families" (Allsop, inside cover).

${ }^{3}$ I use the and/or construction here to denote both the inability of the hobo to remain in one place, in that, at times, he must find work for sustenance that may require him to leave, and his refusal to remain on a particular job. Both are hobo practices. See Anderson.

${ }^{4}$ According to Stephanie Golden, however, hobos boosted their own image in the literature they produced, including the Hobo News, socialist pamphlets, and writings of the road. In their own literature hobos are constructed as "flamboyant, aggressive workingmen, 'with a great sense of pride, self-reliance, and independence,' often politically radical" (Golden 135).

${ }^{5}$ Anderson states that there are two terms employed when authorities speak of vagrancy: wanderlust and dromomania. Both are developed as "a type of pathology of chronic wandering" (xvii). 
When in the city, the hobo may very well "invest in a whole outfit shoes, suit, and overcoat - only to sell them again in a few days when he is broke" (36). This practice of "clothing exchange" takes place at secondhand clothing stores, where "new clothes are on sale at astonishingly low prices ... Much of it is out of date and either shopworn or soiled" (35). While Anderson admits that the secondhand dealer's profit is made in the "coming and going" of the hobo, he also emphasizes that "the veteran hobo knows how to drive a bargain" in this exchange (36).

Likewise, particularly in the winter months, the hobo may choose to sleep indoors, but does so most often in lodging houses that offer a range of affordable accommodations, from "a bed in a single room for fifty cents to a location [on] the floor of an empty loft for a dime" (27). His evening entertainment consists of the "cheap playhouses of Hobohemia" that produce "the show girls who sing or dance in the cheap burlesque theaters." These performances promise "titillations" that are "vulgar and inexpensive" (141). So, too, he typically buys a bottle or two of whiskey and a long-awaited pack of cigarettes, but the majority of his day is spent walking the urban avenues, listening to fellow hobo street orators preach socialism, as well as frequenting the employment bureaus that "offer opportunity for travel" $(172,34)$.

It is this out-of-work or in-between-jobs hobo that proves most threatening to the capitalist city. He is the streetwalker of nonproductive expenditure, whose perceived idleness and ragpicking practices deem him a useless feature of the urban landscape. His mere ambling and inability or refusal to accumulate the newest of commodities results in his being labeled a loiterer and, in turn, he becomes the victim of vagrancy laws that either lead to his incarceration or send him out of town prematurely with the clear message that to be a United States citizen is to own property. ${ }^{6}$

${ }^{6}$ Jack London's account of having been arrested in Niagara Falls (U.S. side) is an example of how hobos were criminalized for their lack of permanent residency. London was sentenced to "thirty days' imprisonment for having no fixed abode and no visible means of support." He reports that after having his "head clipped," his "budding mustache shaved," and his body "compulsorily vaccinated" and "dressed in convict stripes," he became a socialist while "some of his plethoric national patriotism simmered down and leaked out of the bottom of his soul somewhere" (London 100). 


\section{$6 /$ Tapley}

\section{Mapping the American Hobo-Sexual}

Not all hobos are hobo-sexuals, though. As previously mentioned, the hobo-sexual represents an intersection of both not-for-profit work and sex practices. Anderson states that, when he "'goes the limit,", the hobo "may have a hundred reasons for going to town, but the major reason, whether he admits it or not, is to meet women." "Not a marrying man," writes Anderson, "the hobo has few ideal associations with women." Instead, the hobo's "sex relations are naturally illicit." Although the "fortunate" hobos find women who will take them in during the winter months without requiring "the marriage rite," the majority of hobos "are as transient in their attachments to women as to their jobs" (140) and find the "only accessible women are prostitutes" (142). Like most hobo purchases, though, this sexual practice of the hobo is an end in itself; it is based in pleasure and rarely, if ever, leads to a recurrent relationship of intimate exchange precisely because of the hobo's transience.

Further research into the hobo's sexual practices confirms that homosexual activity affects the lives of most hobos. While researchers may disagree on the number of homosexual hobos and the reasons for such a sexual desire, they do agree on a homosexual presence within the hobohemias of any city. Appendix A of Havelock Ellis's Studies in the Psychology of Sex, for instance, is the published correspondence between Ellis and a self-identified "male invert" who claims that there is no distinction between the tramps and hobos of the United States, England, Scotland, and Wales in regard to homosexual practices. "Among both these classes," he writes, "90 percent or I even would be bold enough to say 100 percent indulge in homosexuality when the opportunity occurs" (365). Within this same appendix is a piece entitled "Homosexuality Among Tramps" by Josiah Flynt who claims that "every hobo in the United States knows what 'unnatural intercourse' means, talking about it freely, and, according to my finding, every tenth man practises it, and defends his conduct." Flynt, however, then reduces this prevalent homosexual desire, emphasizing only its ugly cousin, power-play pedophilia. "Boys are the victims of this passion," he writes and continues to explain that hobos "gain possession of these boys" who are "slum children" by seducing 
them with stories of the road and "caresses." According to Flynt, the hobo and the boy are relabeled "jocker" and "prushun" once initiated into this practice, and once on the road, each "prushun ... is compelled by hobo law to let his jocker do with him as he will." Flynt further reiterates the nonconsensual power-relations between prushun and jocker with references to "terrible stories of the physical results to the boy of anal intercourse" (360-61).

A more critical consideration of even Flynt's rhetoric, however, suggests a space of homosexual pleasure. Flynt describes to his audience "one of the worst scenes that can be imagined," consisting of eight hobos who "tripped up and seduced" a boy in a slowly moving freight train outside Cumberland, Pennsylvania. The author describes the anal receiver as having "made almost no resistance, and joked and laughed about the business" (361). Flynt further asserts:

And this, indeed, I find to be the general feeling among boys ... Some of them have told me that they get as much pleasure out of the affair as the jocker does. I have known them to willfully tempt their jockers to intercourse. What the pleasure consists in I cannot say. The youngsters themselves describe it as a delightful tickling sensation in the parts involved ... Those who have passed the age

${ }^{7}$ The jocker is also known as a "wolf" in hobo speak. Likewise, the prushun is regarded as "lamb," "punk," and "fruiter." According to Allsop, these intergenerational relationships were made "edible to the public at large" in such hobo representations as Charlie Chaplin's The Kid of 1921. Allsop argues that the film eclipses homosexual practice by focusing on the punk as apprentice, rather than the run-away poor boy who has been accosted for the sexual pleasures of his adult wolf. The boy's actions (breaking windows) lead to the adult hobo's work (window repair), and the two share the wages. Chaplin explained this relationship in The Kid as one where "the kid and tramp live together, having all sorts of adventures!" In fact, when he approached Jackie Coogan's father about having Jackie play the boy hobo in such a film, Coogan Sr. said, "“Why, of course you can have the little punk." Allsop argues that this reference to punk suggests the "deodorized man-boy relationship" of Platonic tenderness behind which intergenerational hobo homosexual activity resides. Such readings as those of Flynt's, however, do prevail in songs that refer to the jocker tempting the boy with promises of "candy" on the road. The nonsense song The Big Rock Candy Mountains, for instance, is actually a "homosexual tramp serenade or at least a parody of what are known as the 'ghost stories' the accomplished seducer spins to entice a child away." See Allsop 212-25. 
of puberty seem to be satisfied in pretty much the same way that the men are. Among the men the practice is decidedly one of passion. (361-62)

Flynt, in homophobic fashion, goes on to claim that, while there are roughly fifty or sixty thousand hobos in the United States at the end of the nineteenth century, only five or six thousand are into "unnatural or perverted sexual practices" and that these men practice same-sex relations only because there is "one woman for every one hundred men on the road" (360-61).

References both to force and to a lack of women as the primary causes of hobo homosexual activity are standard. Anderson, however, suggests that while isolation and force may very well contribute to homosexual practices, "these accounts serve as a defense reaction on [the writers'] part" (146-47). Considering that Flynt makes himself out to be the only "unwilling witness" (361) in the boxcar above, it is understandable that he would resort to such defense mechanisms.

What I find most intriguing about these sexual practices of the latenineteenth- and early-twentieth-century hobo is that they are, for the most part, eclipsed by an emphasis on the rugged individualism of the male hobo, as well as his homosocial brotherhood. In fact, one of the most popular and prolific of hobo writers, Jack London, mentions neither the homosexual nor the prostitute in his sixty-five page autobiographical "Tramp Diary," written in the spring of 1894. This exclusion of the queer sexuality attested to by historical research suggests to me a publishable, hence a contrived, focus on national homosociality. ${ }^{8}$ Rather, London projects the bonded brotherhood of hobos, their adventures as a fraternal posse marching to Washington, being "ditched" from boxcars or, even better, outwitting the bulls of the railways to get a free ride across America. ${ }^{9}$ Further consideration of London's rhetoric, however, reveals what Eve Kosofsky Sedgwick deems an "erotic triangle."

${ }^{8}$ In essence, Michel Foucault's "talking sex" (77) speaks, but apparently only within the proper genres, those of sociological and medical discourses.

${ }^{9}$ Of course, this same celebrated homosocial network of London's is used against the hobo by the early twentieth century. For instance, Herbert Hoover's "rugged individualism" campaign speech of 1928 is used two years later by capitalist Henry Ford. After putting 75,000 men out of work and on the road as hobos during the Great Depression, Ford argued that "it's the best education in the world for those boys, that travelling around! They get more experience in a few months than they would in years at school" (Davis 272). 
Sedgwick argues that homosociality privileges male-male relations, but it is always regulated and enabled by both homophobia and misogyny (1-27). Therefore, while London's literary production may make no overt reference to the queer sexual practices of the hobo, inherent in his construction of the hobo brotherhood are the disciplinary mechanisms of a discourse on compulsory heterosexuality - the overt fears of an unregulated, nonproductive sexual expenditure - that enable male homosocial privilege.

\section{The Gendered American Hobo-Sexual}

So what of the female hobo? Has she also been erased? Are her sexual practices those of the hobo-sexual? Are they based in pleasure and nonproductive expenditure? Hobo women are, in the words of Thomas Minehan, "as supreme as old-fashioned housewives in the kitchen," performing as property, maintaining the jungle sphere, dependent on the male hobo for sustenance (139-40). Historical research suggests that one girl for every twenty boys takes to the road; Lynn Weiner notes that during the Great Depression of the 1930s, the number of female transients increased to one in every ten persons on the road (173). Hobo girls are actually used as objects of exchange in the hobo jungles, working for the male hobos much like domesticated women do - washing and mending the hobo's clothes, cooking and feeding the hobo collective, as well as making themselves sexually "available to any and all boys in the camps including adults and late arrivals" (Minehan 133-39). There is, however, one other popular option. Once these young girls age and are either no longer desired or choose to set out from the jungle on their own, they more than likely take to urban street walking to earn the money for their sustenance. In fact, Frank Laubach, in his studies of vagrancy, observes that the "female kind of vagrant" is the prostitute (71).

For my purposes, the female prostitute can be read generously as a woman of a hobo work ethic, who traverses the city streets of hobohemia; who intersects with the hobo in sexual practices; and who, in so doing, has the power to challenge the social, economic, and sexual construction of woman so asymmetrical to man. She can be read as an entrepreneur of her own body who works when she likes, the recipient of a tax-free income, and the kind of woman who defies her assigned domestic place. But these latter readings are complicated by a history of American prostitution that reveals a system 
predominantly run by men for men. Stephanie Golden states that the female hobo lived with and performed a sexuality that was constantly controlled in "an objectified, externalized way: when she was not fending off rape, her body was often her working capital" (136). Whether pimp or john, policeman or law, the system seems hinged on male dominance. Even Anderson, in his inclusive hobo typology, develops the prostitute not as a distinct form of hobo, but as a means to male hobo pleasure at a price. She is the "usually forlorn and bedraggled creature" who makes the hobo susceptible to robbery and to venereal infection. The "lowest women who walk the streets," these sex-workers are allowed no pleasure, but instead represent both a means and a threat to the male hobo's wanderlust (142-43). Likewise, the female prostitute's own sexual pleasure is consistently and conveniently eclipsed in American hobo history by an emphasis on her sex work. It is as though, because sex and work collapse in the prostitute's body, she is incapable of sexual pleasure. Or, more probably, she is denied the expression of such.

Golden further asserts that female hobos are denied the "mythology" of the male hobo. While the male version of wanderlust is "elevated into folklore and myth" - its major component one of action and power in the form of an "erratic mobility [that] blended into the nation's manifest destiny" - the female hobo "is immediately and completely defined by her sexuality." She has, in other words, "no place" as a hobo "unless she can be defined as a prostitute" (13839). Likewise, Lynn Weiner contends that women who chose the road and, therefore, "lived outside the family" in the nineteenth and early twentieth century "lost their claim" to the "respectability" inherent in domestic virtues. "For women," she argues, "the term "tramp' came to denote not a transient worker, as it did for men, but rather a sexual outcastes [sic]" (177-78).

In Sister of the Road (1937), Bertha Thompson describes her fifteen years spent in American hobohemias beginning in 1907 when she was born on the road. She introduces her readers to her fond memories of a mother who cooked in the hobo jungles and her three siblings who all had different fathers. Bertha learned her geography and numbers, as well as her alphabet, by studying the writing on the freight trains that frequented her life. Once an adolescent, she rode the rails on her own, spending much of her time in-between rides pickpocketing and begging. She then became a pimped prostitute 
who, in one single afternoon, tested positive for both venereal disease and pregnancy.

Unfortunately, "Box-car" Bertha's autobiography does not speak to her sexual pleasures while a hobo but, instead, of temporary loves external to business (which may very well be the consequence of Dr. Ben L. Reitman's editing of the narrative). Thompson's pleasures come primarily in the form of countercapitalist hobo movements and, in turn, expand the historical female presence within hobo subculture from the mere vessel of male hobo pleasure to the actual agent of hobo anticapitalist practice. In essence, female hobos have their own wanderlust, including their own transient work and sex practices that sometimes come with the risk of disease and the added "hazard" of potential pregnancy (Reitman 285). So, too, there exist other forms of nonproductive expenditure represented by "the lesbians on the road" who are also "bi-sexual ... that is, who liked both men and women and also another group who were prostitutes, selling themselves to men for money but having women sweethearts" (66). This reference to lesbians who work as prostitutes represents, at least in one latent form, the sexual pleasure of prostitutes most typically erased in male hobo literature. "Box-car" Bertha collects other data regarding female hobos that proves useful for a project in connective history. According to Thompson, women leave for the road for various reasons, including sexual desire. And under the heading of female hobo "vices," she lists the "sex irregularities - of the nymphomaniac, the masturbator, and the homosexual or pervert" (283). What classifies these sexual practices as immoral, of course, is that they are irregular. They consist of forms of female sexual desire that are potentially excessive in their pleasure unless regulated and, therefore, may be considered not only vices but outlawed needs.

\section{The Hobo-Sexual of Many Myles}

I suggest reading a particular urban lesbian literature as a part of hobo-sexual history and, in the process, recovering an emphasis on the female hobo's sexual pleasure denied in hobo history, as well as adding a dimension to American lesbian literary history. The urban lesbian character I am most interested in carries forward the unskilled working-class and transient sexual practices of the late-nineteenthand early-twentieth-century hobo and walks against the homophobia and misogyny that are used to regulate and enable the homosocial 


\section{2 / Tapley}

network of privileged male relations. This twentieth-century lesbian hobo-sexual narrative disrupts the traditional emphasis on urban consumerism by revealing the foundation of outlawed social and sexual undesirables on which the profits of U.S. capitalism are produced.

Eileen Myles's 1997 memoir Chelsea Girls encompasses such a hobo-sexual narrative. A nonlinear account of episodic adventures that nurture a narrative style of disjunctions, digressions, and tangents, Chelsea Girls reinvents the American city as a hobo-sexual space of sporadic and spontaneous work and sex practices. Rather than the predictable humdrum of the capitalist machine, the emphasis in Myles's text is one of unanticipated encounters that are fueled by the need for sustenance and the desire to fuck.

In hobo-sexual style, Myles's first-person narrative moves its reader through the back alleys, bars, and bedrooms of New England and New York City. Beginning in Bath, Maine, Myles replaces the images that are traditionally employed in the selling of Maine, a state whose license plate reads "Vacationland." The author challenges the calendar photos of the restored homes of retired sea captains that few can afford, not to mention the picturesque rocky coastline used as a standard backdrop for the icon lobsterman who probably cannot enjoy his serene surroundings for all his concern about his daily sustenance. Instead, Myles tells the unprofitable tale of temporary mill-working lesbians who go on a road trip to Augusta after swallowing much alcohol and a handful of speed. She and her lesbian posse enter a gay bar and disrupt even that apparently queer space. Myles writes:

All the men were taking their shirts off and dancing. We got mad. We wanted to take our shirts off. So we did. Everybody thought it was great. Except for the manager and a couple of fag bartenders. Put 'em on. The men don't have to put their shirts on. Just get out. You can't be in this bar with your shirts off. Put your shirts on and get out. We did. But first we took our pants off. (12)

Needless to say, one would be hard pressed to find such images in any tourist guide. But what I find most intriguing is that Myles remaps the state capital as a space defiant of legislative control. She writes against the grain of a state politics that outlaws the female body.

While in Maine, Myles works at the monotonous job of dipping wooden frames into vats of stain, but such work never dominates the 
narrative. Rather than privilege work over leisure, Myles dismisses the job as simply the unfortunate means to sustenance and, in turn, pleasure. The majority of her time is spent mapping the state of Maine by way of the bars she inhabits, the brawls she finds herself in, and the jail time she serves. But what gains space is her need for sexual pleasure. From "getting all amorous in the back seat of Judy's car with Darragh, her ex-girlfriend" to, only a page later, "happily climb[ing] right on top of Judy" in her "big bed," Myles's desire is transient (12-13). And, like any other hobo-sexual, she leaves the state of Maine "glad to be going off on [her] own" again (17).

As previously mentioned, Myles's narrative is nonlinear, a fact that actually enhances its hobo-sexual practice. It is a collection of prose (much of which had been previously published) that in its anthologized form rejects chronology by disregarding linear history and travel. Readers are required to bounce from city to city, not to mention year to year, and back again, suspending their reliance both on geographical logic and on the time-line proper. But because my narrative is not hobo-sexual, I will continue in a practice of 'anal' geography that simply moves Chelsea Girls south to Massachusetts.

Myles's tales set in lower New England continue in the same hobo-sexual vein, but consist of an earlier history of growing up in the Cambridge area. The daughter of an alcoholic mail carrier who services Harvard Yard, Myles's first person narrator offers a different version of an Ivy League education. "The students at Harvard were rich," she states. "They were always leaving and selling things" (20809). What then follows is a cataloguing of the results of her father's ragpicking adventures. From a hi-fi system and a collection of records, to her father's London Fog and her own drawing pad complete with charcoal pencils, the privileged excesses of Harvard students function, on the one hand, as the detritus of a privileged class while, on the other, as the unexpected treasures of the working poor.

Furthering her working-class education, Myles's narrator takes a job at Filene's Basement in Boston. For the first time, she is labeled "'a transient," "which "sounded right to [her] because [she] had read Grapes of Wrath" (92). Arriving at work hung-over, she moves from counter to counter as needed and, in the process, uncovers the heterogeneous lot who frequent the store known nationwide for its marked-down, name-brand items. Her surroundings include her fellow transients, such as "the black stock clerks from Roxbury, the white 
Irish high school girls, the Jewish women with beehives and big glasses and quite a few concentration camp tattoos on their arms. And they were angry" (92). These are juxtaposed by the shoppers:

Mostly female, mostly white, the black shoppers looked like young beautiful models ... [But] there was also a significant population of gypsies and drag queens who loved to try on floor length gowns. Both of these were said to be major thieves, but mostly the detectives just liked to watch them, I think. (93)

The setting of Filene's Basement, therefore, consists of a dense transfer point of power relations. On the one hand, it is the working class of ethnic, race, and religious diversity that services the homogeneous white female shopper. Even "the black shoppers," for instance, are developed by the simile of the model that suggests like-whiteness. Additionally, it is the bodies of transient desires and work practices, both the Gypsies and drag queens, that are policed most carefully. But, on the other hand, Filene's Basement also suggests a space where the white, or whitelike, female shopper must confront drag queens and Gypsies, and where the gaze of the law is reconsidered the tool of a pleasurable fear.

The narrator's own pleasure is found after hours in the "big plunger kisses" of Gus, who later puts her hand on his crotch during a beach party. She writes, "I liked how warm it felt, all kind of big and bulging. I actually really wanted to do it" (91). Unfortunately, the majority of sexual references accumulated in Massachusetts are based, like the female hobos before her, in domination and exchange. For instance, she spends most of her nights getting "finger fucked" or giving "handjobs" in order to get a ride to the local club because "boys had cars, girls didn' $t$ " (89). So, too, the Massachusetts landscape is haunted with a sexual danger hinged on male dominance. There are references to the gang rapes of Jane Coyne and of the eighteen-year-old narrator herself, a rape that Myles describes as "just a rhythm of many guys" (189).

But Myles's hobo-sexual adventures continue on a more autonomous and pleasurable note in New York City, where she works as a cocaine-dealing cabdriver, as a telemarketer, as a seller of sneakers, and as a waitress, to name only a few of her jobs. 
Each ends with the attitude that is best summed up in the phrase: "I had to quit something, so I quit my job" (168). This flippant antiwork ethic, like that of the hobo-sexual of the late nineteenth and early twentieth century, allows our urban protagonist to roam the city streets, where her unrestrained desires lead to various sexual pleasures. For instance, she masturbates on a bus; fucks many a lesbian; puts her hand on a man's crotch, which "reduces him to a child" (109); as well as has sex with a married couple who were both "being unfaithful at the same time" (164).

\section{Conclusion: A Connective History}

Myles's Chelsea Girls, therefore, can be read as a connecting point in American hobo-sexual history, a textual mapping of sporadic work and sex practices that also has the power to recontextualize the American city as a hobohemia of social and sexual undesirables. Neither Myles's sexual encounters nor her jobs suggest an emphasis on stasis or acquisition. They are, instead, the dynamics of the outlawed need of wanderlust capable of revealing both the homosexual and female pleasure formerly erased by the homosocial network inherent in a traditional American hobo history. Rather than a reappropriation or a resignification of the hobo figure, then, Myles's text actually exposes the homosexual and female presence formerly neglected in a hobo tradition that legitimized itself by mimicking an upper-class narrative of misogyny and homophobia - a homosocial network, however, deemed a national treasure only when linked to the exploitative labor inherent in westward expansion.

It is through this mapping that I hope to have added another dimension to hobo history and lesbian history. But in doing so, I began by making a cross-historical identification between the male hobo and the lesbian, which required, I willingly admit, an initial suspension of any allegiance to gender identity politics. It may appear, then, that all I have accomplished is yet another taxonomy that simply places the lesbian in subordination, under a canopy term of male lineage. But there is no original hobo. There is only the place of cultural-ideological production - a site that has historically favored male homosocial relations and censored homosexual and female sexual space in its construction of tradition - from which I had to start.

My intention in this article has never been to collect the hobo, 


\section{6 / Tapley}

the prostitute, and the lesbian under the heading of hobo-sexual, to gather or group them into a novel homogeneity that erases their differences. Rather, I have constructed the hobo-sexual as a figure in connective history, a narrative able to articulate difference in its very consideration of relations. Embodied in the hobo-sexual are the outlawed needs of human potential that are, according to Rosemary Hennessy, unassimilable under capitalism. Transient work and sex practices are outlawed "because they cannot be brought back into capitalism without abolishing the very terms of the extraction of surplus value" (228). Instead, capitalism assigns hobo-sexual practice to the realm of the working poor and, in the process, manipulates the "basic human needs for food, housing, health care, and also for love and affection, education, leisure time" $(228)$ by producing a surplus labor class able to discipline such potential democratic forms as unions. For as long as there is a transient work force, there exists a threat to job security and the supposed right to renegotiate wages and benefits. Rather than recognize the various needs of human potential, capitalism produces a narrative of illegitimate desires and the consequences of such poor choices. And it employs such a production as a disciplinary mechanism, a threat for the future, that perpetuates the anti-hobo-sexual practice of accumulation. Walking, riding, and writing against this ideology is the hobo-sexual who practices what Bataille asks: "If I am no longer concerned about 'what will be' but about 'what is,' what reason do I have to keep anything in reserve?" (Accursed 58).

My special thanks to Steve Kruger, Adien Dubbelboer, John L. Plews, and Heather Zwicker for their insights, investment and support during the writing of this article.

\section{Works Cited}

Allsop, Kenneth. Hard Travellin': The Hobo and his History. New York: New American, 1967.

Anderson, Nels. The Hobo: The Sociology of the Homeless Man. Chicago: University of Chicago Press, 1923.

Bataille, Georges. The Accursed Share. Vol. 1. Trans. Robert Hurley. 
New York: Urzone, 1988.

—. "The Notion of Expenditure." Visions of Excess: Selected Writings, 1927-1939. Trans. Allan Stoekl, Carl Lovitt, and Donald M. Leslie, Jr. Minneapolis: University of Minnesota Press, 1985. 116-29.

Davis, Kenneth C. Don't Know Much About History. New York: Avon, 1990.

Ellis, Havelock. Studies in the Psychology of Sex. Vol. 1. New York: Random, 1942.

Faludi, Susan. Backlash: The Undeclared War Against American Women. New York: Crown, 1991.

- Stiffed: The Betrayal of the American Man. New York: William Morrow, 1999.

Foucault, Michel. The History of Sexuality. Vol. 1. Trans. Robert Hurley. New York: Random, 1978.

Golden, Stephanie. The Women Outside: Meanings and Myths of Homelessness. Berkeley: University of California Press, 1992.

Hennessy, Rosemary. Profit and Pleasure: Sexual Identities in Late Capitalism. New York: Routledge, 2000.

Laubach, Frank C. Why There Are Vagrants: A Study Based upon an Examination of One Hundred Men. New York: Columbia University Press, 1916.

London, Jack. Jack London on the Road: The Tramp Diary and Other Hobo Writings. Logan: Utah State University Press, 1979.

Minehan, Thomas. Boy and Girl Tramps of America. New York: Farrar and Rinehart, 1934.

Myles, Eileen. Chelsea Girls. Santa Rosa: Black Sparrow, 1997.

Nestle, Joan. "This Huge Light of Yours." A Restricted Country. Ithaca: Firebrand, 1987.

Reitman, Dr. Ben E., ed. Sister of the Road: The Autobiography of Box-car Bertha. New York: Sheridan, 1937.

Schulman, Sarah. Girls, Visions and Everything. Seattle: Seal, 1999. Sedgwick, Eve Kosofsky. Between Men: English Literature and Male Homosocial Desire. New York: Columbia University Press, 1985. Weiner, Lynn. "Women Transients and Tramps." Walking to Work. Ed. Eric H. Monkkonen. Lincoln: University of Nebraska Press, 1984. 